\title{
HIGHER EDUCATION IN AN ERA OF COMPLEXITY: "THE TRIBUTARIES PROJECT" AS A HIGHER EDUCATION HETEROTOPIA
}

\author{
A. M. Hurst* \\ Department of Philosophy, SARChl Chair in Identities and Social Cohesion in Africa \\ e-mail: andrea.hurst@mandela.ac.za / http://orcid.org/0000-0001-5707-2636
}

\section{B. Du Plooy*}

Engagement Office, Engagement and Transformation Division

e-mail: belinda.duplooy@mandela.ac.za / http://orcid.org/0000-0001-5036-1814

\author{
*Nelson Mandela University \\ Port Elizabeth, South Africa
}

\section{ABSTRACT}

Widespread calls to develop modes of teaching and learning in higher education for a paradigm of complexity recognize higher education's double task; namely, to graduate students not only with technical/theoretical expertise, but also the capacity for responsible citizenship. In this article we offer retrospective, philosophical reflections on a South African university engagement project, "The Tributaries Project" (2019). These reflections aim to show that such academic engagement projects, formed as "higher education heterotopia" (a concept co-opted from a 1967 lecture by Michel Foucault) are favourable sites for the second aspect of higher education's task; that is, to foster responsible citizenship among university staff, students and graduates in an era of complexity. Further, Edgar Morin's "seven complex lessons" detail the essential elements of this task, and by extension heterotopic spaces, such as those configured by The Tributaries Project offer ideal conditions for the implementation of Morin's insights. In Part One, we reflect on key theoretical assumptions underlying "The Tributaries Project", via the lens of the concept "heterotopia". Part Two is organised by Edgar Morin's "seven complex lessons", with brief indications of how these lessons were implemented via the project's diverse activities. We hope that sharing insights gained from theorizing, creating and implementing this project may inspire similar projects.

Keywords: higher education, heterotopia, academic engagement, complexity, The Tributaries Project, Edgar Morin, Michel Foucault

\section{INTRODUCTION}

The call for thinkers to re-imagine the world in new ways has become insistent, given increasingly urgent and large scale social and environmental crises. Higher education institutions are called on to become powerful instruments of change through developing modes 
of knowledge creation and dissemination that rise to the challenge of increasing complexity in a rapidly changing and unpredictable world (Mayor, in Morin 1999). Ronald Barnett (2000b) confirms this call, arguing that higher education must develop "a new epistemology" for a milieu of, what he calls, "supercomplexity". Such an epistemology must enable us to negotiate the super-complexities of both multiple, competing theoretical frames and practical (ethical) life (Barnett 2000b, 409). In other words, in a complex era, where uncertainty is the condition, higher education must, of course, impart specialized theoretical knowledge and develop very high levels of technical expertise. However, developing high levels of technical and theoretical expertise is not all that higher education should achieve. It must also foster a broader spectrum of attributes that enable university staff, students and eventual graduates to remain robust at a personal level and flourish in their lives beyond campus as responsible citizens in a complex world. One-sidedly theoretical and instrumental approaches still dominate two core functions of higher education institutions: research and teaching. However, acknowledging the importance of attention to the second part of higher education's task, Barnett's (2000a, 257) identification of triple challenges ("of understanding, of self-identity and of action") dovetails with Edgar Morin's (1999) humanities-based manifesto for re-imagining contemporary education in a complexity-paradigm. The "seven lessons" for higher education in an era of complexity outlined by Morin pertain particularly to the task of fostering graduate attributes required for responsible citizenship: cognitive flexibility (creativity, imagination), social and ethical responsibility, and emotional intelligence (including empathy).

While South African Higher Education Institutions tend to focus on imparting technical and theoretical knowledge in traditional spaces of learning, it remains extremely important to create other spaces for the far less measurable kinds of learning needed to foster the graduate attributes that lead to responsible citizenship. This suggests that a deeper response to the challenges articulated by Morin and Barnett requires more attention, still within the higher education context, to other(ed) spaces, or spaces of othering. The allusion here is to Michel Foucault's (1986) notion of "heterotopia", conceptualised in a 1967 lecture, published in 1984 and translated as "Of Other Spaces: Utopias and Heterotopia" (1986). A key assumption in the reflections to follow is that, as the third core function of higher education, engagement offers a potentially rich environment for the necessary configuring of higher education heterotopia. In other words academic engagement projects, such as The Tributaries Project, formed as "higher education heterotopia", are favourable sites to foster responsible citizenship among educators, students and graduates. Further, these sites offer ideal conditions for the implementation of Morin's Edgar Morin's “seven complex lessons”, which detail the essential elements of this task. 
In the first part of the discussion to follow, we reflect on key theoretical assumptions underlying "The Tributaries Project", via the lens of the concept "heterotopia". In the second part we offer retrospective, philosophical reflections on "The Tributaries Project" (2019). This part is organised by Edgar Morin's “seven complex lessons", with brief indications of how these lessons were implemented via the project's diverse activities. In this discussion we aim to show, via the example of The Tributaries Project, that productive spaces for flexible social, ethical and emotional learning to occur are "higher education heterotopia," since such spaces allow for implementation of Morin's seven lessons through experiential learning. Both educators and graduates can benefit immensely from experiential encounters within such heterotopias, and what is learned may be taken back into more traditional education settings, as educators become better equipped to model socially and ethically responsible modes of being. As explained in more detail below, the non-hierarchical, creative collaboration between a senior lecturer and his music students to produce "water works" is a paradigmatic example of such modelling, which was inspired by The Tributaries Project.

\section{PART ONE: HETEROTOPIA, HIGHER EDUCATION AND ENGAGEMENT}

\section{Foucault and conceptualising heterotopia}

Noting a discursive shift from time to topos or space (simultaneity, juxtaposition and relationality), Foucault (1986, 22-23) argued that understanding ourselves as unitary beings contained in a world, with the future-orientated prospect of a life ahead, has given way to selfidentification in terms of the "sites" (the complex networks of interrelations) that comport us to others and surrounding environments. "University", "academy", "campus", "discipline", "class" and "curriculum" are lexical markers signifying such sites. While respecting Peter Johnson's $(2006,77)$ demurral regarding "site" as a static translation of Foucault's more actively dynamic "espace", we continue to use "site", rather than "emplacement", to remain consistent with Miskowiec's 1986 translation of Foucault's lecture.

Prefiguring the emergence of contemporary network-society (Castells 2009), Foucault $(1986,24)$ describes society as a network of interrelated sites and argues, further, that two kinds of sites are in principle other(ed). If something is "othered" (rather than merely deemed "different"), it remains intrinsically tied to that according to which it is othered. A utopia is othered as the dream of a site's (impossible) perfection. As a fantasy structure of perfect unity, permanently external to an imperfect site, a utopia remains tied to it as the critical mirror that simultaneously represents, contests and inverts it. Foucault's interest lies with sites that share with utopia the externalisation that ties them to a specific site, with the potential this holds for 
reflective critical mirroring. However, these sites are not fantasy structures. They actually exist, and Foucault names them "heterotopia", prefacing topos with hetero (other).

Foucault (1986, 24-27) identifies three kinds of heterotopia: crisis, deviation and compensation. Crisis-heterotopia are sites to which people experiencing crises are temporarily removed from every-day domesticity. Foucault $(1986,25)$ cites boarding schools and military service as examples of the temporary removal of those experiencing the crisis of transition into adulthood. One may include various initiation rites in this category. In contemporary cultures, Foucault argues, crisis-heterotopia increasingly give way to deviation-heterotopia, which temporarily confine individuals whose behaviour deviates from established social norms. Foucault cites prisons, asylums, and psychiatric hospitals as examples, all detailed in other works - Madness and Civilization (1988), The Birth of the Clinic (1973), Discipline and Punish (1975). Both crisis- and deviation-heterotopia are described as sites of illusion: the disorderly are removed from a site to create the illusion that orderliness is normal. Finally, Foucault (1986, 27) argues that the Jesuit colonies in South America exemplify compensation-heterotopia. These work in reverse: groups try to compensate for the chaotic jumble in a site of origin (home) by creating perfectly ordered sites elsewhere.

Attention to only these kinds of heterotopia yields one-sidedly negative senses of othering as "exclusion", "removal" and "confinement" in the name of orderliness. However, Foucault delivered the lecture over fifty years ago, before the "network-society" metaphor had shifted the meaning of otherness towards the more affirmative sense of "diversity". Embracing interrelational diversity is the main principle guiding contemporary discourses of social inclusion. This calls for a corresponding shift in understanding heterotopia, away from their role in underwriting the priority of "order" and towards an affirmation of the necessary, vitalising "disorder" associated with diversity. By noting that heterotopia necessarily take varied forms depending on how a society constructs meaning, and that they change over time as their social functions change, Foucault $(1986,24)$ opens the way for a more complex conception of heterotopia.

A way of re-thinking heterotopia more affirmatively is indicated by the original medical meaning of "heterotopia", which signified "particular tissue that develops at a place other than the usual" (Johnson 2006, 77). As Johnson explains, this does not imply that the tissue is diseased and dangerous. It has merely marked out a position or taken a place elsewhere, and become dislocated. It is essential, though, to retain Foucault's insight regarding the intrinsic bond between a site and its dislocated heterotopia. There can be no identifiable "site" (an interrelation of diverse elements) without a border (however temporary or tenuous) that separates what is specifically incorporated as belonging within and what is excluded. That is, 
heterotopia are co-constituted with an identifiable site, as that which specifically cannot become part of it. The site's cohesiveness depends on maintaining relatively robust self/other borders and the heterotopia therefore underwrite group solidarity or cohesion. Yet, while necessary to a site's identity, heterotopia simultaneously threaten it, by providing a mirroring critique and a place for imaginative alternatives. A healthy site is characterised by ongoing negotiation at its borders, maintaining itself between cohesion and disruption.

Significantly, Foucault ends his lecture by citing "the ship" as the heterotopia par excellence $(1986,27)$. This brings to mind the "ship of fools" that Foucault described in Madness and Civilization (Foucault 1988): a renaissance convention where a society's unwanted (the sick, criminal, insane, and poor) were ejected onto boats that endlessly roamed the oceans. The specific nature of "the ejected" offers a reflective critical mirror of the ejecting society. From an alternative, contemporary perspective one might consider these "fools" as carriers of other forms of wisdom, or what Foucault, in Knowledge/Power (1980), called subjugated knowledges.

\section{Higher education engagement as a site for productive heterotopia}

Viewed through the conceptual lens of "heterotopia", the notion of a "university" has a complex history that warrants a detailed study of its "varied forms" (Foucault 1986, 24). A bare outline must suffice to justify co-opting "heterotopia" to encompass productive higher education engagement spaces. Pierre Hadot $(1995,57)$ informs us that ancient philosophers were called atopos (unclassifiable strangers in the world) in a sense that tied them, through the love of wisdom, to a utopian fantasy of the "perfection of being and knowledge that can only be divine". The desired "perfection of being" was primary, and philosophical schools taught "first and foremost, a way of life", served by knowledge production (Hadot 1995, 269-270). Christianity initiates the shift in our conception of knowledge production from the search for practical wisdom to a "theoretical and abstract activity". Universities, as creations of the medieval church, negotiated the discrepancy between a single faith-based theology and multiple reasonbased philosophies by downgrading philosophy's status as "the supreme science", incorporating its "spiritual exercises" into monastic life, and turning its "conceptual, logical, physical, and metaphysical" tools towards serving theology (Hadot 1995, 270). From the Middle-Ages, knowledge production became "scholastic". As Hadot $(1995,272)$ explains, in the ancient philosophical schools, the designation "philosopher" applied to both the known figures who developed philosophical discourses and those who lived according to their precepts. By contrast, in scholastic universities, education no longer developed human beings, but trained specialists "to train other specialists" (Hadot 1995, 270). 
The first higher education heterotopia, arguably, were created by figures like Descartes and Spinoza, who developed "genuinely creative" new forms of knowing outside theologydominated scholastic universities. However, while heterotopic in relation to scholastic theology, these new ways of knowing were still "situated on the same terrain" as scholasticism in that they remained purely theoretical discourses (Hadot 1995, 271). They were therefore easily absorbed into universities once theology lost its hold. From here on, knowledge in universities, even in "existentialist" discourses, is predominantly constructed as texts of technical jargon, whose dissemination requires specialised exegesis (Hadot 1995, 271). This indeed suggests that universities can be genuine heterotopia vis-à-vis the social system. Situated outside the normative social configurations of family, work and play, they can and do bring students productively into temporary contact with multiple forms of otherness. However, history has also seen the devolution of this heterotopic potential into the elitist, exclusionary and insular "ivory tower". This was, in turn, counteracted by contemporary higher education discourses that advocate re-integration of "town and gown". Largely through Michael Gibbons" (1998), notion of Mode Two societies, engagement became the third core value and function of higher education, alongside teaching and research. In discourses and praxes of engagement, a university is seen as a site, with interrelated responsibilities associated with its locality and social stakeholders. This, however, poses another kind of risk to a university's heterotopic potential. Increasingly plural, populist, massified and commodified higher education spaces become not heterotopic, but destructively conflictual. That is, forces of normative power and control - including, for example, the biopolitics of governmentalism, managerialism, and bureaucratization, and the reduction to instrumental knowledge production in a "business model" - increasingly clash with forces of explosive dissent, divergence and disruption.

Yet, as the closing observation of Foucault's lecture suggests, a healthy site must configure productive, rather than conflictual, spaces of othering. We argue, by extension, that it remains imperative to constitute genuine higher learning heterotopia within a society's institutions of higher education. Vital and flexible universities are not hostile to their heterotopia, but also cannot control or prescribe them. These dis-locations cannot be given a stable space in the institutional fabric without losing their heterotopic character and critical mirroring function, and must in principle remain sites of knowledge production that are functionally and practically external to traditional, sites of learning (classrooms, lecture halls, examinations, tests, political entities, departments, faculties, disciplines, modules, qualifications, curricula). They must remain extra-curricular spaces that offer temporary sanction and space for otherness. In higher education, this implies the kind of experimentation with alternative knowledge production and its "strategic performance" that ideally effects some 
form of change, although this is not predictable or enforceable, which can then be taken back into more conventional institutional sites of traditional teaching and research.

In sum, we consider it imperative to configure engagement spaces, intrinsically connected with research and teaching, but precisely insofar as they provide the necessary "other" to theoretical and instrumental knowledge, are optimal dislocations that enable us to "imaginatively interrogate ... the space in which we live" (Johnson 2006, 75) and experiment with the co-creation of new knowledge. We believe that Tributaries, may be offered as an example of an engagement project that meets this imperative, since, as mentioned, it engaged participants variously in new modes of knowledge creation and dissemination, as articulated by Barnett and Morin.

\section{PART TWO: THE TRIBUTARIES PROJECT}

\section{Overview}

The Tributaries Project was an experimental academic engagement activity, initiated at the beginning of 2019 as part of a larger project, broadly mandated to bring philosophical research, art and experiential learning to bear on questions concerning identities and social cohesion. The aim was to take research and learning out of the four walls of the academy (traditionally the seat of intellectualized, instrumental education, where theoretical knowledge production predominates), based on the conviction that underplayed forms of knowledge, such as art, can play a powerful role in promoting transformative practices of knowing necessary to unbind rigidly held identities, challenge new forms of separatism, and re-imagine identities in ways that might foster social cohesion.

Underpinned by this vision and mandate, The Tributaries Project took shape as the serendipitous confluence of three events. First was the migration of an already existing multidisciplinary art-meets-science engagement project in the Humanities to a newly created institutional structure focused on social cohesion. The idea of an open classroom and collaborative cross-disciplinary engagement with nature was already central to the early project vision. The migration placed heightened emphasis on the connection between ecological and social problems and the insight that social cohesion cannot be isolated from a contemporary global condition of urgent environmental crisis, which requires re-imagining human identity at a species level, in relationship with the environment writ large. Importantly, however, the project was not aimed at directly resolving environmental issues, but at fostering cohesion between diverse individuals around a common topic of concern. As the existing project matured into its second phase in 2019, supported by the university's location in a coastal city, the theme 
of water was adopted.

Second, having walked one of the, life-changing, Camino de Santiago pilgrimage routes, one of the authors began to envisage an equivalent local experience; a "water walk" that would trace a waterway from sea to source. The imagined walk would move from a pristine beach, through industrial zones along the city coastline, before turning upriver into the interior landscape. Gradually leaving the industrial pollution behind, it would end at the river's source in freshwater springs.

Third was the creation of an open seminar series on one of the university's inner-city campuses, initially aimed at facilitating a heterotopic space where art and philosophy could interact. Tying this to the theme of water and opening it to multi-disciplinary participation, a standing open invitation was issued to anyone who wished to present a seminar related to the topic of water.

These three events were configured as a site named The Tributaries Project, which brought together: (1) a regular seminar series that hosted twenty presentations, with lively discussions, during the year; (2) a unique water pilgrimage experience, which, dictated by pragmatics and logistics, became a three-day journey from sea-to-source (rather than a walk), repeated three times for eleven participants each; and (3) all participants were requested to create a creative or academic response to their experience, to be showcased during a culminating week of public events at year-end.

Within the structure outlined, this experimental project proceeded relatively freely according to its own momentum. The symbolism associated with Tributaries - "flow", "confluence" and "outflow" - fits exceptionally well with Foucault's metaphor of a heterotopic ship, mooring in multiple harbours with an uncertain destination. This is consonant with Johnson's $(2006,87)$ understanding of heterotopia as "fundamentally disturbing experiences" that "offer no resolution or consolation, but disrupt and test our customary notions of ourselves". They "contest forms of anticipatory utopianism", he adds, and "hold no promise or space of liberation". But for these reasons, they also open "a passage for our imagination".

\section{Insights gained}

The Tributaries Project grew in ways that retroactively justified its name, becoming different things for diverse participants and gathering to itself a confluence of interests and passions. Acknowledging that the project overflows attempts to reflect on its entirety, we share insights gained from our experiences, organized by Morin's Seven Complex Lessons in Education for the Future (1999). Casting "education" as both theoretical and practical knowledge production, Morin (1999: 1-4) outlines "seven facets" that should become "essential knowledge" in all 
higher education contexts. These dovetail well with intuitions guiding the project's creation and evoke the gist of what we learnt from the project's implementation.

Because Morin's (1999, 3-4) seventh lesson - embrace a complex ethos of self, society and environment - integrates and unifies the others, it offers an appropriate way to indicate how his seven lessons may be pulled together to inform the task of fostering responsible citizenship, and how this, in turn, helps us gather together our dispersed reflections on Tributaries. Morin argues that higher education bears the important responsibility of extending beyond intellectual life, to develop a broader ethos (Harries 1997, 4). One may think of this ethos, the ethical spirit of the community, as a complex of three aspects: care of the self (developing individual autonomy); regulating social relationships (community participation); and constructing sustainable living environments (earth stewardship). In academia today the prevailing discourses of "humanising pedagogy," "indigenous knowledge systems" and "decolonization", often devolve into a nostalgic longing to return to an imagined utopia before some form of disruption occurred. Developing Foucault's concept of heterotopia and tying it to Morin's humanities-based manifesto for educating in complexity, we have tried to make the case that re-imaging higher education through a discourse of complex heterotopia, rather than utopia, opens productive sites for reimagining selves and communities in ways that enable humans to live well within an environment of overwhelming complexity or supercomplexity. Without pretending to know how to change the course of the impending environmental crisis, we see wide scope in Tributaries for more formalized research within the growing field of environmental humanities, which insists on building a complex ethos which gathers together self, society and nature. Assuming, with Morin and others that widespread change requires a fundamental re-casting of our identity as humans, to build a complex ethos that includes the relationships we have with others and the world at large, we hope to show in what follows that Tributaries managed to: (1) trigger substantial re-thinking of identity and belonging among individual participants; (2) bind participants together in a group characterised by differentiated cohesion; (3) dislocate habitual perceptions and ways of thinking; and (4) introduce some therapeutic ways in which to creatively and imaginatively deal with the complexity of human thought patterns and behaviour, particularly as related to the traumatising ecological crises and contemporary anxieties about being in the world.

\section{Lesson 1: Reflect on what counts as knowledge}

Morin $(1999,1)$ argues for integrating reflection into every discipline on what counts as knowledge. Dedicated training in detecting conditions that produce "error and illusion" and in evaluating on-line knowledge sources is increasingly imperative. However, without denying 
the necessity of "achieving lucidity", Morin's injunction also implies that knowledge is more than clear, accurate, theoretical and factual content of instrumental value. Morin (2011) insists: "We must stop identifying education with high productivity, with the mercantile and the professional", and recognise that knowledge also entails "knowing how" to live well. Morin (2011) cites "Jean Jacques Rousseau's idea that learning to live means learning to live poetically". "Knowledge" is accordingly extended to encompass insight gained from inter alia "aesthetics, music, painting, and art" (Morin 2011), and responsible engagement with "subjugated knowledges". Foucault $(1980,81-82)$ describes these as "knowledges that have been disqualified as inadequate to the task or insufficiently elaborated; naive knowledges, located low down on the hierarchy, beneath the required level of cognition or scientificity". Through these, he adds, "criticism performs its work".

Tributaries exemplified the latter part of Morin's first lesson. The project created diverse opportunities for experimental, experiential learning that dislocated participants from habitual patterns of academic knowledge production (theoretical, instrumental and content-based) and made conspicuous the idea of seeking "know-how" directed towards living well. Such insight, as argued, is best sought in higher education heterotopia. The project's three Sea-to-Source pilgrimages were configured as such heterotopia, where participants committed to a full threeday journey, relinquishing work and domestic responsibilities for the duration. Notably, access to devices, while not intentionally restricted, was limited by localities and activities. One of the reversals important to the project was to engage with experts in sites other than lecture halls, through relationships other than "chalk and talk," and via oral discourses rather than texts. Further, aesthetic learning (stimulating the imagination through close attention to our full sensory relationship with the material world) was central to the project. Aesthetic learning requires a person to be "out there", open to concrete encounters that transcend egotism and attune the senses to the material world. To foster such aesthetic learning, participants were requested up-front to produce a response to their experience, and artwork was encouraged across the disciplines. Many produced both artworks and academic papers. Without denying the importance of theoretical reflection, but undoing its dominance, participant's conceptions regarding what counts as knowledge, were broadened through the attention paid to responsible engagement with subjugated knowledges. For example, one participant delivered an early seminar presentation on water's spiritual significance in Xhosa culture, a theme that was picked up during the pilgrimages, when participants serendipitously encountered locals enacting rituals in the sea and river water. Indeed, the pilgrimages themselves were configured as heterotopic experiments in ritual-creation without any associated dogma. This attention to the subjugated knowledges found in cultural practices repeatedly sparked animated discussions around 
indigenous knowledge, how alternative voices and traditions can be silenced by dominant ones, and how such knowledge may be recognised in the academy.

\section{Lesson 2: Foster inter- and multi-disciplinarity}

Because exclusively discipline-bound research and teaching generates "fragmented learning" that is inadequate for understanding a (super)complex contemporary world, Morin $(1999,1)$ advocates developing inter- and multi-disciplinary practices that enable us to see how partial, circumscribed forms of disciplinary knowledge contribute to "the bigger picture". Tributaries participants were diverse in many respects, including: age; race; gender; physical ability; academic positioning (students and staff members at every level); relationships (strangers, colleagues, life-partners, friends, mother-son and mother-daughter). We must, however, here acknowledge that, aside from one high school pupil (who participated with an academic parent), all participants were, or had been, involved in the academic world. This may have predisposed the group to a certain type and level of engagement, and it would be interesting to see if the same principles and assumptions would hold, with inclusion of participants from beyond the university-level of proficiency. Within the specificity of an academic site, Tributaries participants spanned a diversity of interests, with multidisciplinary representation across the academic spectrum, from Art, Education, Chemistry, Literature, Music, Sociology, Philosophy, Development Studies and Botany. Finally, non-experts encountered water experts who offered activities, presentations and/or site tours. From this diversity, a group of entirely voluntary participants cohered for the project's duration.

Three factors, we believe, were key to successfully holding such a diverse, multidisciplinary group together. First, a guiding assumption in the project's formation, motivating the choice to focus on water, was that group cohesion depends on a shared concern/passion around which project members constellate. This motivated the choice to focus on water, which networked the project into a global concern, a strong local concern among citizens of a droughtvulnerable city, and the ocean-sciences focus of the university where the project was located. A second assumption was that cohesion in a diverse multi-disciplinary group required the continuity of a regular, specifically heterotopic meeting space to share ideas. This requirement was met by the seminar series, configured as a non-hierarchical, open space where participants related to one another on equal terms, and something beyond traditional teaching and learning was encouraged. Presenters ranged from first year to postdoctoral students, from academic to non-academic staff members, and from new academics to experienced senior professors. Thirdly, it was assumed that group cohesion would be fostered by working towards a shared goal. Accordingly, project participants were informed from the start that creative or academic 
outputs would be performed, exhibited or presented at a culminating week of public events at the year's end. Notably, this culminating performance of the individual and collective knowledge gained from diverse disciplines and perspectives, provided a visible enactment of Morin's lesson regarding interdependence, mutuality and the humble acknowledgement that each discipline makes only a partial contribution to addressing general, fundamental problems.

\section{Lesson 3: Tie knowledge production to reflection on the human condition}

Morin $(1999,1 ; 2014)$ argues that education should engender awareness of the complex unity of "the human adventure we have all embarked upon now in this planetary era". Yet, education practices predominantly reflect the fractured way of conceptualising human nature most clearly seen in anthropocentrism (belief in the superiority and domination of humanity over other forms of life). As a heterotopic space that dislocated participants from habitually anthropocentric patterns of thinking, Tributaries offered strong experiential confirmation of what many "already know" intellectually regarding the interconnectedness of humans, other creatures and materials in complex global networks. Actual encounters with water as a carrying medium for globalised pollution dominated the Tributaries experience. Every water source encountered (sea, estuary, river, spring) yielded visible plastic waste, nurdles nestled among shells, and the realisation that water carries microplastics "everywhere" was compounded by the viscerally shocking site tour of a local wastewater treatment works and the warning at the edge of a beautiful river-to-sea estuary not to dip as much as a finger in it because of its toxicity due to industrial and urban waste pollution. Such experiences elicited a common sense of revulsion and abject horror, but also a keen new perspective on the taken-for-granted, out-of-sight-out-of-mind processes of everyday life; flushing toilets, for example, and opening taps. Presentations during seminars repeatedly referred to site-visits and experts' talks during pilgrimages and the role of humanity in local and global relationships to/with non-human others became a recurring discussion point. These contributed to a deeper understanding of the intersecting systems of knowledge that configure the complex human condition, which is often experienced as the dilemma created by simultaneous and conflicting needs and desires. For example, the global human need for clean running water implies the potentially polluting industry and infrastructure that provide this; or the necessity of convenient, efficient and massive waste disposal clashes with the desire to preserve pristine natural environments.

\section{Lesson 4: Make earth citizenship an indispensable aspect of education}

For Morin $(1999,4)$ the human condition as a network of interdependent organic and nonorganic entities, and the complex configuration of planetary crises imposes the responsibility 
of educating all humans to take a considered stance towards earth citizenship. Three key aspects of this responsibility formed part of the Tributaries project methodology: taking a stance, taking action, and public sharing.

While emphasizing the imperative to take a stance, no opinion was imposed regarding what that stance should be, and participants engaged in a spontaneous, on-going negotiation of optimism and pessimism in light of grave, global "life and death" challenges. Although participants shared a commitment to improve troubling socio-environmental conditions, the extreme complexity of articulating what this means both philosophically and practically became apparent after the first pilgrimage, when an overwhelming despondency affected the participants quite severely. From this experience, two extremely important insights emerged.

Firstly, during the day-two check-in a pilgrim astutely articulated her personal experience of debilitating "eco-grief" and her efforts to counteract this with restorative, joyful encounters that remind her of what she is fighting for. This spontaneously verbalised something implicit in the pilgrimage structure and explicitly set the emotional tone for the final day, where pilgrims moved from the toxic river mouth to its source in a relatively pristine wilderness area. Here the pilgrimage was competed on foot, to a point where it was safe to scoop water into hands and drink it. The relationship between eco-grief, joyful encounters and action became a strong theme for the duration of the project. In subsequent pilgrimages, organisers became mindful of maintaining the double sense of grievous horror and joyful awe that resounds in the word "respect", triggered by encounters with that which transcends everyday perspectives and triggers the imagination. The horror that affected participants around overwhelming global water crises was juxtaposed with increased reference to occasions for a sense of awe. On one pilgrimage, for example, pilgrims reflected a sense of awe at the sight of whales breaching just off the coast, at the resilience of birds able to adapt global migration patterns around the climate crisis; and, for some, in immersing themselves in the pristine waters where the pilgrimages ended. This "strategic performance," subsequent to the first pilgrimage, produced a visible enactment of the deep-seated existential knowledge that humans seek out the ineffable deep at the core of their own being (awe) for the self-renewal necessary for resilience in a world that includes interaction with the darker side of life and of human being (horror).

Secondly, from the risk of generating a one-sided experience of ego-grief, the realisation grew that the complex task of taking a stand (whether pessimistic, optimistic, or paradoxical) should accompanied by experimentation in forms of taking action. Even Foucault, often accused of pessimism, makes a case for activism. He insists "not that everything is bad, but that everything is dangerous" (Foucault in Grimshaw 1993, 123). Danger leaves no room for depressed apathy, but calls for "a hyper- and pessimistic activism". Through on-site 
presentations and tours by local NGOs, organisations, and scientists, all pilgrimage participants encountered examples of efforts to take action through, for example, community information and education; scientific research, and eco-responsible entrepreneurship. In response to the pessimistic sense of despondency emerging on the first pilgrimage, it was decided to integrate opportunities for experiments in activism. Beach clean-ups (organised by local NGOs) were integrated into subsequent pilgrimages and, thanks to serendipitous timing, pilgrims on the third participated in a local protest event that formed part of the larger global climate strike. Again, it must be emphasised that the strategy was to offer opportunities for experiments in active participation, without imposing any specific agenda. Overall, the experience of collective action in the beach clean-ups generated an affirmative response of solidarity and investment into the group, prompting sustained involvement with the project for its duration, and reportedly changed perspectives from which there is no return. Integrating such activities, which have a life after the pilgrimage, also counteracted the danger of the inevitable "come down" from the high intensity engagement in a heterotopic space.

The final key aspect of the responsibility Tributaries assumed towards earth-citizenship education was to make it possible for participants to publicly share and declare the learning and change they achieved and experienced during the project processes and events. All participants were offered the opportunity to showcase responses during a culminating week of project events. In a characteristic reversal, the week's programme was not outlined in advance. Rather, participants were free to produce any kind of response and within budget and logistical constraints, occasion was made to showcase it. One participant, for example, composed a 4part musical piece in collaboration with a group of his music students, and wished to perform it at the close of a music colloquium. At his request, we scheduled the opening of the Tributaries events to coincide with this performance, serendipitously creating a delightful crossover between otherwise unrelated occasions. Other responses included performance artwork, exhibition of visual artwork, reading of poetry and creative writing, and a day of formal academic presentations. Some participants also shared their responses during 2019. A fine example was an extensive performance art protest against plastic pollution inspired by a student's experiences on the first pilgrimage. This enduring, highly-mediated and ultimately award-winning action campaign gained local, national and then international attention. Further examples of public sharing include a podcast recorded by one of the participants and a short video produced about the project. During 2020, an on-line exhibition catalogue will be produced, and formal academic presentations, supported by a week-long writing workshop, are being worked into publishable journal articles.

As suggested by a perspicacious reviewer, the interrelationship between "taking a stance", 
"taking action", and "public sharing", form essential aspects the broader higher education task and may be considered in terms of the core functions of higher education (Learning and Teaching, Research and Engagement). Their interrelationship in higher education may be outlined as follows. Within a complexity paradigm, it is essential to be aware that multidimensionality is the fundamental condition of human life, and this means that there are necessarily multiple possible, and equally viable positions for academics (and people in general) to take on any issue, which render different courses of action and results. Academics cannot remain paralysed by the intrinsic uncertainty associated with this complexity, and must, within their disciplines, take a carefully considered stance on the important issues, in order to teach responsibly and to model responsible learning practices. The emphasis here is on careful consideration, with due humility, and reasonable flexibility regarding modifications to any stance. This integrates responsible teaching and learning with ongoing, life-long learning and research practices. While there is an ethical imperative to produce academic work that enables action to address social, ethical and emotional problems, there is never enough knowledge to help us choose with complete certainty the best way to do this. This is why public sharing of problems, perspectives, ways of responding to them and outcomes, and openness to public debate, is an essential part of all higher education. If what is shared in traditional academic formats (seminars, colloquia, and academic journals) is accompanied by public sharing in multiple other formats, such as performance artwork, art exhibitions and literary work, public sharing reaches a far wider audience, and generates wider interest and further learning. Of course, public sharing must negotiate the significant limitations that allow for motivated and mendacious creation and sharing of false information. But this limitation underscores the vital need to pay more attention to the task of Higher Education to foster the graduate attributes that lead to responsible citizenship.

\section{Lesson 5: Embrace uncertainty}

While prediction and control is the dream that persistently motivates knowledge acquisition and dissemination, uncertainty is more characteristic of the human condition. Morin proposes the task of developing minds that are prepared for uncertainty and able to configure appropriately flexible strategies to deal with chance encounters and unexpected events. With a Foucaultian ring, Morin (2014) remarks: "Living is like sailing on an ocean of uncertainty through archipelagos of certainty". Barnett (2000a, 257) too, postulates a supercomplex world of continual conceptual challenge "where nothing can be taken for granted, where no frame of understanding or of action can be entertained with any security". Morin (2011) explains that "strategy", emerging from the exigencies of war, aims "to make us adaptive to changing 
environments". In an era of endemic uncertainty, Morin (2014) notes, teaching the art of strategy is imperative, and this involves teaching the art "changing one's behaviour in accordance with the information we receive".

At is very core, Tributaries embraced as far as possible the kind of uncertainty that demands "strategic action" from its participants. In the first pilgrimage, both organisers and participants embarked on a journey for the first time, and although the basic sea-to-source structure of subsequent pilgrimages remained the same, both felt like new journeys, not only because of the specific configuration of personalities and capacities in each group, but also because different elements (e.g. beach clean-up, protest action, site tour of river mouth) and different practical configurations (number of vehicles, accommodation sites, expert presenters) were experimentally introduced in response to feedback and pragmatic contingencies. Pilgrimages were also characterised by a paradoxical leadership style. On one hand, organisers held the broad structure together, with a significant degree of pre-planning (and luck) to ensure that logistics ran smoothly enough to disappear into the background. On the other hand, project organisers were participant-leaders, who left participants relatively autonomous in multiple ways. One participant observed that the leadership style tended to "put the group in crisis", reiterating in effect, "I don't know where this is going - what do you suggest we do"? Strategic action was encouraged by fragmenting leadership roles. For example, additional vehicle-drivers were drawn from the group, and on the day-hikes, the organisers walked behind the group, allowing a natural hike-leader to emerge from within. Social, emotional and informational leadership roles also emerged as contexts called for them. Pilgrimage activities were made available, but nothing was mandatory aside from commitment to the full three days and the daily group check-in.

Further, the weekly seminars were not planned long in advance. Spontaneous groups and conversations formed during and outside of seminars, generating ideas and volunteers for future seminars. Importantly, participation was on an entirely voluntary basis, participants were welcome to come and go as they pleased and to invite others. There was no external reward for participating nor penalty for not doing so. Thus the project remained open to the fluidity and flow of each situation, as determined by the unique dynamics of each group encounter and the subsequent larger project narrative that developed.

In short, Tributaries can accurately be described as a communally owned, hands-on, bottom-up project that was not preconceived or pre-planned beyond the basic idea of: a regular seminar series, an experiential pilgrimage experience and a publicly sharable response by participants to their experience of the project. Importantly, we remain convinced that any attempt at formalization, institutionalization and curriculation (thus making it part of 
compulsory assessable coursework with a pass or fail result) would contradict the aim of producing heterotopia where critiquing and challenging, as well and bonding and cohesiveness, can play out in uncertain and organic ways that cannot be predicted or controlled and therefore encourage the kind of strategic action Morin describes as suitable for living with complexity.

\section{Lesson 6: Foster mutual understanding in all directions}

Morin $(1999,3)$ argues that globalisation makes it all the more important for education to foster mutual understanding in all directions among inexorably diverse human beings, across the multiple axes of social division (inter alia generations, races, genders, nations, political and religious factions). More than escaping "socio-centrism" ("believing that one's own society is true and what happens elsewhere is bizarre, crazy or meaningless"), Morin (2011) notes that the challenge begins with "individualist ego-centrism" whereby individuals posit themselves as unquestionably in the right, and misrepresent others by reducing them to "the most detestable aspect of their person". Agreeing with Morin that education should enable individuals to "see the multiple aspects of the other", Tributaries was not aimed at solving an environmental problem. "Water" was, as one participant noted, more an alibi to entice people into each other's spaces, out of comfort zones and into encounters with one another that, due to ingrained academic hierarchies, they otherwise would not have had. Indeed, a key assumption of Tributaries was that to re-imagine human identities, in ways that allow cohesive relationships with others to form, these others need to be experienced in non-threatening, non-hierarchical ways. It was, for example, extremely valuable to share the levelling experiences of sleeping on the ground in tents, sharing basic overnight accommodation with relative strangers, eating around a fire, and hiking in the wilderness.

Even though the project attracted deeply different approaches, attitudes and personalities there was almost no conflict. Despite some heated discussions and disagreements about various issues, the discursive markers and attitudinal traits of agitation, provocation and disruption, prevalent in contemporary higher education debates, were absent from this space, and the core group of participants kept returning to the project. In a time when antagonism and conflict seem to be more the norm than the exception in higher education contexts, this was a surprising outcome. Without external influencing by the organisers, this heterotopia organically formed itself as a depoliticised space, self-regulated so that it did not become a soap box for any one idea or person; no participant tried to stake a claim, win an argument or discredit another participant or position. This affirmed the act of generosity and dignity that is inherent in sharing spaces with one another and the validation of oneself and another in the act of listening to, hearing and seeing one another. The performance of the musical work created by one of the 
participants to a public audience is a salient example of this. The progression of the musical piece, which participants collectively came to call "the water work", was often discussed in seminars and participants. These contributions in turn again inspired the composer in his structuring of the music piece. The creation and execution of the performance was also a collaborative project between the composer (a music lecturer) and his students, resulting in the combination of classical, contemporary jazz and traditional African musical styles; the use of all three local languages (Afrikaans, Xhosa and English) in the musical score; and the use of conventional orchestral instruments (piano, bass and guitar) with traditional instruments created from, for example, seed pods, and even the "playing" of water as an instrument.

Agreeing with Johnson $(2006,86)$ that heterotopia can be "a form of escape without the comfort of home", Tributaries became a haven from the confrontationalism that dominates the academic institutional space, and an affirmative site of fun, play and joy (words that are sadly lacking in many academic discourses). As a site of heterotopic experience, Tributaries facilitated a deep awareness of the need for more supple and subtle human systems of engagement that allow for holding more than one idea, opinion, want, need and desire at the same time, and that, though being a deeply complex and paradoxical experience, this can manifest as a sense of fun, play and joy, when shared with like-minded others.

\section{CONCLUDING REMARKS}

Consistently reiterated among all three groups of pilgrims and the broader group of Tributaries participants, was the question of finding ways to incorporate and sustain insights gained from Tributaries experiences in daily living. One of the ways forward for heterotopic projects such as Tributaries is to integrate more explicitly some of the therapeutic and self-transformative exercises that Pierre Hadot (1995) describes in Philosophy as a Way of Life. Such practices facilitate in individuals the sustained contemplative, rather than instrumental, attitudes that disengage some of the multiple forces underlying "individualist ego-centrism". Part of this task remains intellectual, including, for example, re-imagining some of these "spiritual exercises" for a more contemporary condition of complexity, and assessing Hadot's $(1995,207)$ critique of Foucault (1988) for seeing "technologies of self" purely in terms of individual selftransformation.

The project has significant potential for future outflows towards wider community participation. Within the university, interest in further participation was generated, especially after the culminating week of events, and new staff and students have expressed interest in participating in another incarnation of the project. This is proposed for 2020/2021 as a collaboration with ocean sciences, through the vehicle of a postdoctoral research project. To 
maintain continuity with the Tributaries year (2019) that we are reporting on here, the weekly seminar has continued under the thematic banner of "Drop in the Ocean". Responding to conference and seminar presentations on Tributaries, academics from several other universities (local and international) have expressed interest in possibilities of replication and/or collaboration. Likewise, civic and non-profit organisations have indicated their interest in the project and much potential exists for further collaboration. Exactly what a next phase of Tributaries will look like, beyond the initial year that we are reporting on here is still uncertain. The retrospective evaluative and conceptualisation process, of which this article is one part, will help us work out whether and how Tributaries will continue. What is clear, however, is that the unique organic nature of the project must not be lost through institutionalisation, reduplication and/or commercialisation.

In this project, micro-events and -forces converged serendipitously in ways that only become retrospectively linear. By extension, we have offered a logically structured narrative of an event what was essentially undefinably complex and nuanced, and in the year of its duration grew far beyond what was imagined at first. We do so in the hope that our experience in creating and theorizing such a heterotopic engagement space may inspire similar projects, adapted to the unique specificities of other institutions, and provide impetus for further multi-disciplinary and collaborative initiatives, in classrooms and on campuses, in fieldwork, and in-between the often siloed domains of disciplinary knowledge.

\section{ACKNOWLEGDEMENT}

This work is based on the research supported by the National Research Foundation of South Africa (Grant Number 99188, SARChI Chair in Identities and Social Cohesion in Africa, Nelson Mandela University). Opinions, findings, conclusions and recommendations expressed in this work are those of the authors alone and the NRF accepts no liability whatsoever in this regard.

\section{REFERENCES}

Barnett, Ronald. 2000a. "Supercomplexity and the Curriculum." Studies in Higher Education 25(3): 255-265. https://doi.org/10.1080/713696156.

Barnett, Ronald. 2000b. "University Knowledge in an Age of Supercomplexity." Higher Education 40: 409-422. https://doi.org/10.1023/A:1004159513741.

Castells, Manuel. 2009. The Rise of the Network Society. John Wiley \& Sons. Hoboken, New Jersey.

Foucault, Michel. 1973. The Birth of the Clinic: An Archaeology of Medical Perception, translated by Alan Sheridan-Smith. New York: Vintage Books.

Foucault, Michel. 1975. Discipline and Punish: The Birth of the Prison, translated by Alan Sheridan. Paris: Gallimard. 
Foucault, Michel. 1980. Power/knowledge: Selected Interviews and Other Writings, 1972-1977, ed. Colin Gordon. New York: Vintage Books.

Foucault, Michel. 1986. "Of Other Spaces: Utopias and Heterotopias," translated by Jay Miskowiec. Diacritics 16(1) Spring: 22-27. Johns Hopkins University Press, https://doi.org/10.2307/464648.

Foucault, Michel. 1988. Madness and Civilization: A History of Insanity in the Age of Reason. New York: Vintage Books.

Gibbons, Michael. 1998. "Higher Education Relevance in the 21st Century." Prepared for the UNESCO World Conference on Higher Education. Paris, France. 5-9 October. http://Wwwwds.Worldbank. Org/Servlet/Wdscontentserver/WDSP/IB/2000/07/19/000094946_9912220532351/Rendered/PD F/Multi_Page.pdf.

Hadot, Pierre. 1995. Philosophy as a Way of Life, translated by Michael Chase. Oxford: Blackwell.

Harries, Karsten. 1997. "Introduction: Postmodern Prelude". In The Ethical Function of Architecture, 2-13. Massachusetts: MIT Press.

Johnson, Peter. 2006. "Unravelling Foucault's 'Different Spaces'." History of the Human Sciences 19(4): 75-90. https://doi.org/10.1177/0952695106069669.

Morin, Edgar. 1999. Seven Complex Lessons in Education for the Future, translated by Nidra Poller. Paris: UNESCO.

Morin, Edgar. 2011. "Seven Complex Lessons in Education.” Wise Channel Interview, 14 November. https://www.youtube.com/watch?v=oUfqZE-Ywts.

Morin, Edgar. 2014. "WISE 2013 Special Address: Dr Edgar Morin.” Wise Channel, 8 July. https://www.youtube.com/watch?v=c9ddx6m_5Yw. 